\title{
Effects of a Smartphone Overdependence Prevention Program on Self-esteem, Self-efficacy, and Peer Relations in Elementary Students Enrolled in a Community Children's Center
}

\section{스마트폰 과의존 예방 프로그램이 지역아동센터를 이용하는 초등학생의 자존감, 자기효능감, 또래관계에 미치는 영향}

Ae Jeong Park ${ }^{1}$ 박애정 ${ }^{1}$

${ }^{1}$ Student, Department of Addiction Rehabilitation Counseling, Namseoul University Graduate School, Republic of Korea, ajlove8@naver.com

\begin{abstract}
The aim of this study is to design and implement a smartphone overdependence prevention program for elementary school students enrolled in a community children's center, and examine its effects on their self-esteem, self-efficacy, and peer relations. The study was designed as a six-sessionslong program, and 67 elementary school students from a community children's center in South Chungcheong Province( 34 in experimental and 33 in control groups) participated in the study. This study has used the measures of scales for over-dependence on smartphone, self-esteem, sdlf-efficacy, an peer relations; while statistical analysis has been done based on independent sample $T$ validation and covariance analysis from the SPSS 22.0 program. The results showed that the program reduced the students' smartphone overdependence, and improved their self-esteem, self-efficacy, and peer relations. One can find the significance of the study as its design and implementation of a program accounting for the vulnerability of elementary school students in need of protection and attention from the society, as well as providing empirical data for preventing smartphone overdependence in this group.
\end{abstract}

Keywords: Community Children's Center, Smartphone Overdependence, Self-esteem, Self-efficacy, Peer Relations

요약: 본 연구의 목적은 지역아동센터를 이용하는 초등학생을 대상으로 한 스마트폰 과의존 예방 프로그램을 고안하고 실행하여 지역아동센터를 이용하는 초등학생의 자존감, 자기효능감, 또래 관계에 미치는 효과를 알아보는 데 있다. 고안된 프로그램은 6회기로 충청남도 소재의 지역아동센터 초등학생 67명(실험집단 34명, 통제집단 33명)을 대상으로 프로그램을 실시하여 효과성을 검증하였다. 연구에 사용한 척도는 스마트폰 과의존 척도, 자존감 척도, 자기효능감 척도, 또래 관계 척도를 사용하였으며 통계분석은 SPSS 22.0 프로그램을 사용하여 독립표본 $\mathrm{T}$ 검증, 공분산 분석을 하였다. 그 결과, 스마트폰 과의존 예방

Received: December 24, 2020; $1^{\text {st }}$ Review Result: February 4, 2021; $2^{\text {nd }}$ Review Result: March 29, 2021 Accepted: April 30, 2021 
프로그램이 지역아동센터를 이용하는 초등학생의 스마트폰 과의존을 감소시키고 자존감, 자기 효능감, 또래 관계를 향상하는 데 효과가 있었다. 사회적으로 보호와 관심이 있어야 하는 사각지대의 특수성을 고려한 프로그램을 구안하고 실행하여 스마트폰 과의존의 예방을 위한 실천적 자료를 제공하는 데 의의가 있다.

핵심어: 지역아동센터, 스마트폰 과의존, 자존감, 자기효능감, 또래 관계

\section{1. 서론}

스마트폰은 게임, 영화 및 동영상, 음악, 각종 정보 등 다양한 기능과 편리한 기능으로 인해 우리의 생활에 필수품이 되었다. 특히 코로나 19 로 인하여 자유롭게 외출할 수 없 어 스마트폰을 사용하여 화상 수업, 장보기 등 온라인상에서 모든 일이 가능해지고 있다.

스마트폰의 장점과 더불어 다양한 문제들이 발생하고 있다. 정보화 진흥원[1]의 스마트 폰 과의존 실태조사에 의하면 스마트폰 이용자 5 명 중 1 명은 스마트폰 과의존 위험 상태 로 나타났으며 청소년의 스마트폰 과의존 비율이 가장 높았다. 이러한 스마트폰 과의존 은 시력 저하, 거북목, 손목터널증후군 등 신체적 건강을 해칠 수 있으며[2] 분노, 집중력 감소, 무기력, 불안, 우울 등 정신 건강 상태뿐만 아니라[3] 또래 관계나 사회성 발달을 가로막는 등[4] 다양한 영역에서 부정적인 영향을 미친다.

특히 스마트폰 과의존은 맞벌이 가정과 한 부모 가정인 경우 과의존 위험에 취약하다 고 하였다[1]. 지역아동센터를 이용하는 아동 - 청소년의 경우 양부모 가정에서 맞벌이 가 정 아동이 가장 많이 이용하는 것으로 나타났으며[5] 다수가 저소득층 및 해체된 가족 등 역기능적 가정의 아동이 이용하고 있는 것으로 나타났다[6]. 이러한 역기능적 가정환경으 로 인해 지역아동센터를 이용하는 아동들은 다양한 정서적 어려움을 겪을 가능성이 크 다. 지역아동센터 아동의 자아존중감은 일반 아동보다 상대적으로 낮다고 연구 결과에 나타났는데[7] 자존감이 낮을수록 스마트폰을 과다 사용하는 결과를 얻었다[8]. 또한 부모 의 보호 및 관심 부족으로 인하여 스마트폰에 더욱 의존하게 되며[9] 정서적으로 안정감 이 부족하여 적절한 대인관계를 형성하기 어려워 부적응을 초래할 수 있다[10]. 이는 아 동들이 또래들로부터 소외감을 많이 느낄수록 휴대전화 의존도가 높은 것으로 나타났다 [11].

지금까지의 선행연구를 검토하면 예방 프로그램은 일반 아동·청소년들을 대상으로 실시한 연구들이 대부분이며 지역아동센터를 이용하는 초등학생들에게 실시한 스마트폰 예방 프로그램에 관한 연구는 부족한 실정이다. 이에 이 연구의 목적은 지역아동센터를 이용하는 초등학생들을 위한 스마트폰 과의존 예방 프로그램을 구안하여 그 효과성을 검증하는 데 있다. 이 연구 문제는 다음과 같다. 스마트폰 과의존 예방 프로그램이 지역아동센터를 이용하는 초등학생들의 스마트폰 과의존을 감소시키는가? 스마트폰 과의존 예방 프로그램이 지역아동센터를 이용하는 초등학생들의 자존감, 자기효능감, 또래 관계를 증진하게 시키는가? 


\section{2. 연구 방법}

\section{1 연구대상}

본 연구는 충청남도 당진시, 홍성군, 태안군 소재의 지역아동센터를 이용하는 초등학생 총 67 명 $(4,5,6$ 학년)을 대상으로 실시하였으며 실험집단 34 명, 통제집단 33 명의 아동이 참여하였다.

\section{2 연구 도구}

본 연구에서는 스마트폰 과의존, 자존감, 자기효능감, 또래 관계의 효과성에 대해 자기 보고식 질문지를 사용하였다.

\subsection{1 스마트폰 중독 진단 척도}

본 연구에서는 스마트폰 과의존의 수준을 측정하기 위하여 한국정보화진흥원[12]에서 개발한 청소년용 스마트폰 중독 진단 척도를 사용하였다. 스마트폰 중독 진단 척도의 하위 요인은 일상생활 장애(5문항), 가상세계 지향성(2문항), 금단(2문항), 내성(4문항)으로 총 15 개 문항으로 구성되어 있다. 각 문항은 4점 Liker 식 척도로 점수가 높을수록 스마트폰 과의존의 위험이 높은 것을 의미한다. 이 검사의 신뢰도(Cronbach's $\alpha)$ 는 .75이었다.

\subsection{2 자존감 척도}

자존감 척도는 Coopersmith(1967)가 개발한 Self-esteem Inventory(SEI)를 최보가와 전귀연이[13] 번안하고 타당도와 신뢰도를 검증한 척도를 사용하였다. 자존감 척도의 하위요인은 일반적 자존감(6문항), 사회적 자존감(9문항), 가정적 자존감(9문항)으로 총 32 문항으로 구성되어 있다. 각 문항은 5점 Liker 식 척도로 점수가 높을수록 자존감이 높은 것을 의미한다. 이 검사의 신뢰도(Cronbach’s $\alpha$ )는 .92이었다.

\subsection{3 자기효능감 척도}

자기효능감 척도는 김아영과 차정은이[14] 개발한 척도를 사용하였다. 자기효능감 척도의 하위요인은 자기효능 자신감(7문항), 자기효능 자기조절(12문항), 자기효능 과제 난이 선호(5문항)로 총 24문항으로 구성되어 있다. 각 문항은 5점 Liker 식 척도로 점수가 높을수록 자기효능감이 높은 것을 의미한다. 이 검사의 신뢰도(Cronbach’s $\alpha$ )는 .83이었다.

\subsection{4 또래 관계 척도}

또래 관계의 척도는 Buhrmester와 Furman(1985)이 제작한 Network of Relationships Inventory(NRI)를 한종혜가[15] 번안하여 타당도와 신뢰도를 검증한 척도를 사용하였다. 또래 관계 척도의 하위요인은 사회적 지지(17문항), 처벌 및 주도권(6문항), 친밀(4문항), 우의(3문항), 대립(3문항)으로 총 33문항으로 구성되어 있다. 각 문항은 5점 Liker 식 척도로 점수가 높을수록 또래 관계의 정도가 높은 것을 의미한다. 이 검사의 신뢰도(Cronbach’s $\alpha$ )는 .91이었다. 
Effects of a Smartphone Overdependence Prevention Program on Self-esteem, Self-efficacy, and Peer Relations in Elementary Students Enrolled in a Community Children's Center

\section{3 연구 절차}

지역아동센터를 이용하는 초등학생을 대상으로 한 스마트폰 예방 프로그램을 재구성하기 위해 기존 스마트폰 과의존 예방 프로그램[16][17]에 대한 연구를 검토하였다. 예방 프로그램의 구성요소, 각 회기의 목표와 프로그램 내용 등을 추출한 후 전문가 3 인에게 내용 타당도를 검증받았다. 자문 위원의 검토 및 보안 사항을 참고하여 수정한 지역아동센터를 이용하는 초등학생을 대상으로 한 스마트폰 과의존 예방 프로그램을 최종 고안하였으며 아래 [표 1]과 같다.

[표 1] 스마트폰 과의존 예방프로그램

[Table 1] Smartphone Overdependence Prevention Program

\begin{tabular}{|c|c|c|}
\hline 회기 & 구성요소 & 프로그램 내용 \\
\hline 1 & 스마트폰 인식 & $\begin{array}{l}\text { 집단원 간의 친밀감과 신뢰감 형성 } \\
\text { 스마트폰 기능의 장단점 알기 } \\
\text { 스마트폰 과다사용으로 인한 문제점 인식하기 }\end{array}$ \\
\hline 2 & 자기인식 & $\begin{array}{l}\text { 스마트폰 사용에 대한 자기인식 } \\
\text { 변화되고 싶은 모습 찾기 } \\
\text { 구체적인 변화의 목표 정하기 }\end{array}$ \\
\hline 3 & 자기인식 & $\begin{array}{l}\text { 스마트폰에 대한 나의 욕구 탐색하기 } \\
\text { 스마트폰에 사용에 대한 양가감정 탐색하기 } \\
\text { 부정적 감정 제거하기 }\end{array}$ \\
\hline 4 & 자기수용 & $\begin{array}{l}\text { 스마트폰의 오남용 상황 인식하기 } \\
\text { 오남용 상황에서 효율적인 대처 방법 탐색하기 } \\
\text { 오남용에 대처할 수 있는 자원 찾기 }\end{array}$ \\
\hline 5 & 자기수용 & $\begin{array}{l}\text { 나의 꿈 탐색하기 } \\
\text { 꿈과 스마트폰 사용 계획 세우기 } \\
\text { 팀별 꿈 로드맵 만들기 }\end{array}$ \\
\hline 6 & 자기수용 & $\begin{array}{l}\text { 지금까지 변화된 자신을 발견, 지지하고 칭찬하기 } \\
\text { 건전한 스마트 사용 실천 의지 다짐 }\end{array}$ \\
\hline
\end{tabular}

\section{4 자료처리 및 분석}

본 연구의 분석 방법은 SPSS 22.0을 이용하여 실시하였다. 실험집단과 통제집단 간 일반적 특성의 동질성 검증을 위해 사전검사를 Pearson $\chi^{2}$ (카이제곱)으로 분석하였으며 스마트폰 과의존, 자존감, 자기효능감, 또래 관계에 대한 실험집단과 통제집단의 동질성 검증을 위해 독립표본 $\mathrm{T}$ 검증을 하였다. 그런 후에 실험집단과 통제집단의 사전-사후 검사 점수 간에 차이를 분석하기 위해 공분산 분석을 하였다.

\section{5 연구 결과}

\subsection{1 실험집단 및 통제집단의 동질성 검사}

실험집단과 통제집단의 특성을 파악하기 위한 일반현황은 성별, 가족 구성원, 부모 국적, 형제 수, 종교를 조사하였다. 이 변수들은 모두 명목척도로 조사되었으며 설험집단과 
통제집단의 동질성을 측정하기 위해 Pearson $\chi^{2}$ (카이제곱) 분석을 하였으며 그 결과는 아래 [표 2]와 같다.

분석 결과 실험집단과 통제집단 간에 성별, 가족 구성원, 부모 국적, 형제 수, 종교에서 $95 \%$ 신뢰수준에서 차이가 없는 것으로 나타났다. 즉 이들 항목에 대해서 실험집단과 통제집단은 동질의 집단으로 볼 수 있다.

[표 2] 실험-통제집단의 동질성 검사 결과: 일반현황

[Table 2] Homogeneity of the Experimental and Control Groups: General Characteristics

\begin{tabular}{|c|c|c|c|c|}
\hline \multicolumn{2}{|c|}{ 구분 } & 실험집단 & 통제집단 & $\chi^{2}$ 값 \\
\hline \multirow{2}{*}{ 성별 } & 남자 & 10 & 13 & \multirow{2}{*}{.740} \\
\hline & 여자 & 24 & 20 & \\
\hline \multirow{3}{*}{$\begin{array}{l}\text { 가족 } \\
\text { 구성 원 }\end{array}$} & 부모 & 24 & 23 & \multirow{3}{*}{1.059} \\
\hline & 한부모 & 9 & 10 & \\
\hline & 친인척 & 1 & 0 & \\
\hline \multirow{2}{*}{$\begin{array}{l}\text { 부모 } \\
\text { 국적 }\end{array}$} & 부모 모두 한국 & 25 & 19 & \multirow{2}{*}{1.994} \\
\hline & 아버지만 한국 & 8 & 13 & \\
\hline
\end{tabular}

\subsection{2 스마트폰 과의존}

실험의 효과를 검증하기 위하여 공분산 분석 결과를 실시하였으며 그 결과는 아래 [표 3]과 같다.

[표 3] 실험-통제집단의 사전 - 사후 검사와 공분산 분석에 의한 조정된 사후검사 결과 비교 [Table 3] Pre-test, Post-test, and Adjusted Results in ANCOVA for the Experimental and Control Groups

\begin{tabular}{|c|c|c|c|c|c|c|c|}
\hline \multirow{2}{*}{ 구분 } & \multicolumn{2}{|c|}{ 사전 } & \multicolumn{2}{c|}{ 사후 } & \multicolumn{2}{c|}{ 조정된 사후 } \\
\cline { 2 - 8 } & 평균 & 표준편차 & 평균 & 표준편차 & 평균 & 표준편차 \\
\hline \multirow{2}{*}{$\begin{array}{c}\text { 스마트폰 } \\
\text { 과의존 }\end{array}$} & 실험집단 & 2.137 & .364 & 1.955 & .338 & 1.933 & .046 \\
\cline { 2 - 8 } & 통제집단 & 2.063 & .335 & 2.238 & .344 & 2.261 & .047 \\
\hline
\end{tabular}

*는 $\mathrm{p}<0.05,{ }^{* *}$ 는 $\mathrm{p}<0.01,{ }^{* * *}$ 는 $\mathrm{p}<0.001$ 을 의미함.

스마트폰 과의존에 대한 실험집단과 통제집단의 사전검사와 사후검사의 평균값을 비교한 결과, 실험집단은 사전검사보다 사후검사에서 감소했지만, 통제집단은 
Effects of a Smartphone Overdependence Prevention Program on Self-esteem, Self-efficacy, and Peer Relations in Elementary Students Enrolled in a Community Children's Center

사전검사보다 사후검사에서 증가하였다. 공분산 분석을 통해 조정된 사후검사는 사후검사와 큰 차이가 없었다.

실험집단과 통제집단 간에 통계적으로 유의미한 차이가 있는 것으로 나타났다. 이는 스마트폰 과의존 수준이 감소한 것은 실험 처치의 효과라고 볼 수 있다.

[표 4] 스마트폰 의존, 자존감, 또래 관계, 자기효능감 검사의 총점 공분산 분석 결과

[Table 4] ANOCVA of Smartphone Dependence, Self-esteem, Peer Relations, and Self-efficacy Scores

\begin{tabular}{|c|c|c|c|c|c|}
\hline 구분 & 변량원 & 제곱합 & 자유도 & 평균 제곱 & $\mathbf{F}$ \\
\hline \multirow{4}{*}{$\begin{array}{c}\text { 사후- } \\
\text { 스마트폰 } \\
\text { 의존 }\end{array}$} & $\begin{array}{c}\text { 공변량 } \\
\text { (사전검사) }\end{array}$ & 2.957 & 1 & 2.957 & $41.102 * * *$ \\
\hline & $\begin{array}{c}\text { 주효과 } \\
\text { (실험/통제집단) }\end{array}$ & 1.791 & 1 & 1.791 & $24.891 * * *$ \\
\hline & 잔차 & 4.605 & 64 & .072 & \\
\hline & 총계 & 302.840 & 67 & & \\
\hline
\end{tabular}

\subsection{3 자존감}

실험의 효과를 검증하기 위하여 공분산 분석 결과를 실시하였으며 그 결과는 아래 [표 5]와 같다.

[표 5] 실험-통제집단의 사전 - 사후 검사와 공분산 분석에 의한 조정된 사후검사 결과 비교 [Table 5] Pre-test, Post-test, and Adjusted Results in ANCOVA for the Experimental and Control Groups

\begin{tabular}{|c|c|c|c|c|c|c|c|}
\hline \multirow{2}{*}{\multicolumn{2}{|c|}{ 구분 }} & \multicolumn{2}{|c|}{ 사전 } & \multicolumn{2}{c|}{ 사후 } & \multicolumn{2}{c|}{ 조정된 사후 } \\
\cline { 2 - 8 } & 평균 & 표준편차 & 평균 & 표준편차 & 평균 & 표준편차 \\
\hline \multirow{3}{*}{ 자존감 } & 실험집단 & 2.323 & .506 & 2.295 & .489 & 2.389 & .039 \\
\cline { 2 - 8 } & 통제집단 & 2.549 & .490 & 2.623 & .458 & 2.526 & .039 \\
\hline
\end{tabular}

*는 $\mathrm{p}<0.05,{ }^{* *}$ 는 $\mathrm{p}<0.01,{ }^{* * *}$ 는 $\mathrm{p}<0.001$ 을 의미함.

자존감에 대한 실험집단은 사전검사보다 사후검사의 평균점수가 높아졌지만, 통제집단은 사후검사에서 사전검사보다 낮아졌다. 자존감의 조정된 사후검사 값은 사후검사보다 실험집단은 높아지고, 통제집단은 낮아졌다.

[표 6] 스마트폰 의존, 자존감, 또래 관계, 자기효능감 검사의 총점 공분산 분석 결과

[Table 6] ANOCVA of Smartphone Dependence, Self-esteem, Peer Relations, and Self-efficacy Scores 


\begin{tabular}{|c|c|c|c|c|c|}
\hline 구분 & 변량원 & 제곱합 & 자유도 & 평균 제곱 & F \\
\hline \multirow{4}{*}{$\begin{array}{c}\text { 공변량 } \\
\text { (사전검사) } \\
\text { 자존감 }\end{array}$} & $\begin{array}{c}\text { 주효과 } \\
\text { (실험/통제집단) }\end{array}$ & 11.444 & 1 & 11.444 & $231.958^{* * *}$ \\
\cline { 2 - 6 } & 잔차 & 3.158 & 64 & .299 & $6.060^{*}$ \\
\cline { 2 - 6 } & 총계 & 420.749 & 67 & .049 & \\
\hline
\end{tabular}

*는 $\mathrm{p}<0.05, * *$ 는 $\mathrm{p}<0.01, * * *$ 는 $\mathrm{p}<0.001$ 을 의미함.

실험집단과 통제집단 간에 통계적으로 유의미한 차이가 있는 것으로 나타났다. 따라서 자존감이 향상된 것은 실험 처치의 효과라고 볼 수 있다.

\subsection{4 자기효능감}

실험의 효과를 검증하기 위하여 공분산 분석 결과를 실시하였으며 그 결과는 아래 [표 7]과 같다.

[표 7] 실험-통제집단의 사전 - 사후 검사와 공분산 분석에 의한 조정된 사후검사 결과 비교 [Table 7] Pre-test, Post-test, and Adjusted Results in ANCOVA for the Experimental and Control Groups

\begin{tabular}{|c|c|c|c|c|c|c|c|}
\hline \multicolumn{2}{|c|}{} & \multicolumn{2}{|c|}{ 사전 } & \multicolumn{3}{c|}{ 사후 } & \multicolumn{2}{c|}{ 조정된 사후 } \\
\cline { 2 - 8 } & 평균 & 표준편차 & 평균 & 표준편차 & 평균 & 표준편차 \\
\hline \multirow{2}{*}{ 자기효능감 } & 실험집단 & 3.229 & .425 & 3.360 & .311 & 3.365 & .040 \\
\cline { 2 - 8 } & 통제집단 & 3.245 & .434 & 3.240 & .404 & 3.235 & .041 \\
\hline
\end{tabular}

*는 $\mathrm{p}<0.05, * *$ 는 $\mathrm{p}<0.01, * * *$ 는 $\mathrm{p}<0.001$ 을 의미함.

자기효능감은 실험집단은 사전검사 값보다 사후검사의 평균점수가 높아졌고, 통제집단은 사전조사와 사후조사 값이 비슷하였다. 자기효능감의 조정된 사후검사 값은 사후조사 값과 유사하게 나타났다.

[표 8] 스마트폰 의존, 자존감, 또래 관계, 자기효능감 검사의 총점 공분산 분석 결과

[Table 8] ANOCVA of Smartphone Dependence, Self-esteem, Peer Relations, and Self-efficacy Scores

\begin{tabular}{|c|c|c|c|c|c|}
\hline 구분 & 변량원 & 제곱합 & 자유도 & 평균 제곱 & $\mathbf{F}$ \\
\hline \multirow{2}{*}{$\begin{array}{c}\text { 사후_- } \\
\text { 자기효능감 }\end{array}$} & $\begin{array}{c}\text { 공변량 } \\
\text { (사전검사) }\end{array}$ & 4.871 & 1 & 4.871 & $87.836^{* * *}$ \\
\hline & $\begin{array}{c}\text { 주효과 } \\
\text { (실험/통제집단) }\end{array}$ & .285 & 1 & .285 & $5.137^{*}$ \\
\hline
\end{tabular}


Effects of a Smartphone Overdependence Prevention Program on Self-esteem, Self-efficacy, and Peer Relations in Elementary

\begin{tabular}{|l|c|c|c|c|c|}
\hline & 잔차 & 3.549 & 64 & .055 & \\
\cline { 2 - 6 } & 총계 & 738.733 & 67 & & \\
\hline
\end{tabular}

*는 $\mathrm{p}<0.05,{ }^{* *}$ 는 $\mathrm{p}<0.01,{ }^{* * *}$ 는 $\mathrm{p}<0.001$ 을 의미함.

실험집단과 통제집단 간에 통계적으로 유의미한 차이가 있는 것으로 나타났다. 따라서 자기효능감이 이 향상된 것은 실험 처치의 효과라고 볼 수 있다.

\subsection{5 또래 관계}

실험의 효과를 검증하기 위하여 공분산 분석 결과를 시행하였으며 그 결과는 아래 [표 9]와 같다.

[표 9] 실험-통제집단의 사전 - 사후 검사와 공분산 분석에 의한 조정된 사후검사 결과 비교

[Table 9] Pre-test, Post-test, and Adjusted Results in ANCOVA for the Experimental and Control Groups

\begin{tabular}{|c|c|c|c|c|c|c|c|}
\hline \multirow{2}{*}{\multicolumn{2}{|c|}{ 구분 }} & \multicolumn{2}{|c|}{ 사전 } & \multicolumn{2}{c|}{ 사후 조정된 사후 } \\
\cline { 2 - 8 } & 평균 & 표준편차 & 평균 & 표준편차 & \multicolumn{2}{|c|}{ 평균 } & 표준편차 \\
\hline \multirow{2}{*}{ 또래 관계 } & 실험집단 & 3.106 & .776 & 3.530 & .579 & 3.635 & .075 \\
\cline { 2 - 8 } & 통제집단 & 3.506 & .546 & 3.398 & .530 & 3.289 & .076 \\
\hline
\end{tabular}

*는 $\mathrm{p}<0.05,{ }^{* *}$ 는 $\mathrm{p}<0.01,{ }^{* * *}$ 는 $\mathrm{p}<0.001$ 을 의미함.

또래 관계는 실험집단은 사전검사보다 사후검사 평균 점수가 높아졌고, 통제집단은 낮아졌다. 또래 관계의 조정된 사후검사 평균값은 사후검사 값보다 실험집단은 높아지고, 통제집단은 낮아졌다.

[표 10] 스마트폰 의존, 자존감, 또래 관계, 자기효능감 검사의 총점 공분산 분석 결과

[Table 10] ANOCVA of Smartphone Dependence, Self-esteem, Peer Relations, and Self-efficacy Scores

\begin{tabular}{|c|c|c|c|c|c|}
\hline 구분 & 변량원 & 제곱합 & 자유도 & 평균 제곱 & F \\
\hline \multirow{4}{*}{$\begin{array}{c}\text { 사후 } \\
\text { 또래관계 }\end{array}$} & $\begin{array}{c}\text { 공변량 } \\
\text { (사전검사) }\end{array}$ & 8.370 & 1 & 8.370 & $45.839^{* * *}$ \\
\cline { 2 - 6 } & \begin{tabular}{c} 
주효과 \\
\cline { 2 - 6 }
\end{tabular} & 1.837 & 1 & 1.837 & $10.063^{* *}$ \\
\cline { 2 - 6 } & 잔차 & 11.685 & 64 & .183 & \\
\cline { 2 - 6 } & 총계 & 824.743 & 67 & & \\
\hline
\end{tabular}

*는 $p<0.05, * *$ 는 $p<0.01,{ }^{* * *}$ 는 $p<0.001$ 을 의미함. 
실험집단과 통제집단 간에 통계적으로 유의미한 차이가 있는 것으로 나타났다. 따라서 또래 관계가 향상된 것은 실험 처치의 효과라고 볼 수 있다.

\section{3. 결론}

본 연구는 스마트폰 과의존 예방 프로그램을 통하여 지역아동센터를 이용하는 초등학 생의 자존감, 자기효능감, 또래 관계에 미치는 효과에 대해 알아보고자 하였다. 연구 결 과를 토대로 논의하면 다음과 같다.

첫째, 본 연구의 스마트폰 과의존 예방 프로그램은 지역아동센터를 이용하는 초등학생 의 스마트폰 과의존을 감소시키는 데 효과가 있었다. 이는 지역아동센터를 이용하는 초 등학생의 환경적, 물리적 등 특성을 고려하여 차별화된 스마트폰 과의존 예방 프로그램 개발을 하였다는 것에 의의가 있다. 또한 스마트폰 사용하는 연령이 점차 낮아지고 있으 며 특히 지역아동센터 아동의 스마트폰 보유율이 지속해서 증가하고 있어 습관이 형성될 무렵인 초등학교나 그 이전부터도 예방 교육이 중요하므로 치료프로그램이 아닌 예방 차 원의 프로그램이라는 데 큰 의의가 있다. 스마트폰 사용의 잘못된 습관은 스마트폰 중독 현상을 야기한다는 연구 결과와도 맥을 같이한다고 볼 수 있다[18].

둘째, 본 연구의 과의존 예방 프로그램은 지역아동센터를 이용하는 초등학생의 자존감 및 자기효능감을 증진하는 데 효과가 있었다. 이는 스마트폰의 부정적인 측면이 아닌 긍 정적인 측면과 대처 방법을 강화함으로써 자존감과 자기효능감이 증진된 것으로 보인 다. 스마트폰의 과다사용은 자존감이 낮은 사람들의 욕구를 채우기 위한 공간으로 활용 될 가능성이 커 자존감과 효능감이 낮을수록 스마트폰 중독이 높다는 연구 결과와 일치 한다[3].

셋째, 본연구의 과의존 예방 프로그램은 지역아동센터를 이용하는 초등학생의 또래 관 계를 증진하는 데 효과가 있었다. 이는 과의존 예방 프로그램을 진행하면서 집단 원들과 의 긍정적인 상호작용을 통해 타인과의 친밀감 및 신뢰감을 형성함으로써 또래 관계를 향상하는 데 효과적이라는 것을 시사한다. 긍정적인 친구 관계를 경험할수록 스마트폰 사용량이 적고 긍정적으로 건강한 스마트폰 사용 습관을 기를 수 있다는 연구 결과를 뒷 받침한다[19].

본 연구의 제한점 및 후속 연구에 대한 제언은 다음과 같다. 이 연구는 충청남도에서 있는 초등학생 4 6학년을 대상으로 이루어졌으며 실험집단의 참가 인원을 고려하였을 때 전체의 지역아동센터를 이용하는 초등학생들에게 연구 결과를 일반화하기에는 어려움이 있다. 둘째, 실험 처치 투입 기간이 짧다는 데 한계가 있다. 총 6 회기로 매회 80 분씩의 단회기 프로그램을 실시한 후 효과를 검증하였기에 프로그램 효과의 지속성에 대해 검증을 하지 못하였다. 이러한 측면을 고려하였을 후속 연구에서는 장기화한 프로그램과 지속적인 효과를 검증할 필요가 있겠다.

\section{References}

[1] Survey of smartphone overdependence, National Information Society Agency, (2019)

[2] I. S. Lee, M. H. Lee, H. K. Kim, J. S. Park, J. H. Son, A study on the internet game and smartphone usage of the senior 
elementary school children, Journal of the Korea Academia-Industrial Cooperation Society, (2020), Vol.21, No.10, pp.421-432,

[3] C. J. Park, S. J. Seo, M. A. Do, Trends of domestic research on smartphone addiction among elementary, middle, and high school students: Focusing on the causes and results of smartphone addiction, Journal of Emotional \& Behavioral Disorders, (2017), Vol.33, No.3, pp. 271-296, http://dx.doi.org/10.33770/JEBD.33.3.14

[4] M. A. Lee, H. J. Seo, The effects of the parent-children relationship and peer attachment on mobile phone dependency of adolescent using community child center- the mediating effect of ego-resilience, Journal of Child Welfare and Development, (2018), Vol.16, No.2, pp.87-107.

[5] Statistical report of community children's centers nationwide, Headquarters for Community Child Center, (2019)

[6] M. A. Lee, An influence of the reality therapeutic group art therapy on internal-external control, and happiness of children in community children centers, Daegu Haany University, Doctoral dissertation, (2017)

[7] Survey of community children's centers nationwide: End of December 2014, Headquarters for Community Child Center, (2015)

[8] J. E. Choi, K. J. Kim, The interpersonal skills of nursing college students, self-esteem, and overuse of smart phones, Asia-Pacific Journal of Multimedia Services Convergent with Art, Humanities, and Sociology, (2018), Vol.9, No.7, pp.397-408, http://dx.doi.org/10.35873/ajmahs.2019.9.7.036

[9] Y. C. Kim, Relationship among peer attachment, ego-resiliency, and mobile phone dependence of community children's center for children, Asia-Pacific Journal of Multimedia Services Convergent with Art, Humanities, and Sociology, (2016), Vol.6, No.3, pp.145-157, http://dx.doi.org/10.14257/AJMAHS.2016.03.11

[10] H. K. Kim, The effect of perceived parental abuse and neglect and peer attachment on school life adjustment according to children's gender, Family and Environment Research, (2014), Vol.52, No.1, pp.11-19, DOI : 10.6115/fer.2014.52.1.11

[11] K. M. Kim, J. E. Song, Effects of parent's neglect and feeling of isolation in peer relations on cell phone dependence in children using community children's centers: Focused on the latent growth model, Research Institute of Education Kore University, (2018), Vol.31, No.2, pp.25-42.

[12] 2011 Study of developing a smartphone addiction diagnostic scale, National Information Society Agency, (2011)

[13] B. G. Choi, K. Y. Jeon, A study on the development of the Self-Esteem Inventory (I), Journal of the Korean Home Economics Association, (1993), Vol.31, No.2, pp.41-54.

[14] A. Y. Kim, J. E. Cha, Self-efficacy and measurement, Korean Journal of Industrial and Organizational Psychology, (1996), pp.51-64.

[15] J. H. Han, Relationship between parents' character and parenting attitude and school-aged children's character, Seoul National University, Master's thesis, (1980)

[16] H. S. Lee, H. S. Kim, The effectiveness of smartphone addiction prevention program for upper elementary students, Korean Journal of Child Psychology, (2019), Vol.14, No.2, pp.37-57.

[17] S. R. Chung, H. K. Yoo, S. I. Nam, Development of a group counseling program to prevent addiction to smartphones in a potential risk group of middle school students, Korea Journal of Counseling, (2014), Vol.15, No.3, pp.1145-1162, DOI : $10.15703 / \mathrm{kjc} .15 .3 .201406 .1145$

[18] Y. M. Kim, D. B. Kim, Mediating Effects of Self-Control on the Relationship between Smartphone Use and School Adjustment in Middle School Students, Korean Journal of Youth Studies, (2016), Vol.23, No.3, pp.133-162, UCI : G704-000387.2016.23.3.016

[19] H. S. Cho, J. K. Kang, D. M. Kang, The effects of interpersonal relationship group counseling program for preventing internet and smartphone addiction, The Korean Journal Child Education, (2019), Vol.28, Vol.3, No.pp.169-182. 